\title{
Process Water Recirculation During Hydrothermal Carbonization as a Promising Process Step Towards the Production of N-doped Carbonaceous Materials
}

\section{Dominik Wüst ( Dominik.Wust@unitn.it)}

University of Trento: Universita degli Studi di Trento https://orcid.org/0000-0002-0981-4938

\section{Pablo Arauzo}

University of Hohenheim: Universitat Hohenheim

\section{Sonja Habicht}

Karlsruhe Institute of Technology: Karlsruher Institut fur Technologie

\section{Fernando Cazana}

University of Zaragoza: Universidad de Zaragoza

Luca Fiori

University of Trento: Universita degli Studi di Trento https://orcid.org/0000-0002-9693-2384

\section{Andrea Kruse}

University of Hohenheim: Universitat Hohenheim https://orcid.org/0000-0003-0892-1966

\section{Research Article}

Keywords: ioeconomy, Biorefinery, Hydrothermal Carbonization, process water recirculation, Maillard reaction, $\mathrm{N}$-doped carbonaceous materials.

Posted Date: February 24th, 2021

DOI: https://doi.org/10.21203/rs.3.rs-232186/v1

License: (c) (i) This work is licensed under a Creative Commons Attribution 4.0 International License. Read Full License 


\section{Abstract}

Hydrothermal Carbonization (HTC) refers to the conversion of biogenic wastes into char-like solids with promising perspectives for application, but a process water (PW) results which is difficult to dispose untreated. Thus, a biorefinery approach including one or two recirculation steps with the additional objective of improving the physico-chemical characteristics of the solid was performed. During HTC, constitutive biomass molecules decompose into hundreds of organic compounds, following complex reactions. To get deeper insights a combination of proximate, ultimate and structural analysis for solid products as well as liquid chromatography for liquid products were the choice. The main reactions could be identified by key compounds of low and high molecular weight resulting from hydrolysis, dehydration, decarboxylation, deamination as well as amide formation and condensation reactions. Their intensity was influenced by the feedwater $\mathrm{pH}$ and reaction temperature. Reactions of Maillard character result in $\mathrm{N}$ containing heterocycles incorporated into the hydrochar (HC), which promises the fabrication of high added-value materials, i.e. N-doped carbonaceous materials.

\section{Full Text}

Due to technical limitations, full-text HTML conversion of this manuscript could not be completed. However, the latest manuscript can be downloaded and accessed as a PDF.

\section{Figures}

A

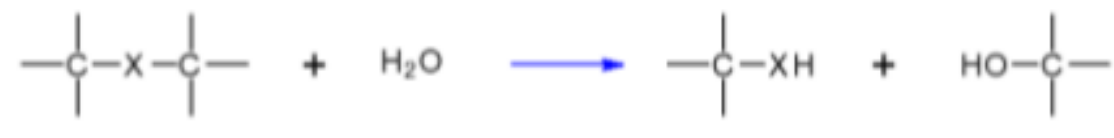

$\mathrm{x}=\mathrm{O}, \mathrm{NH}, \mathrm{S}$

B

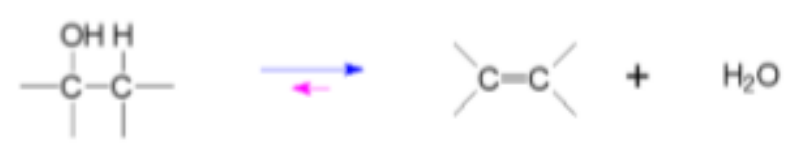

C
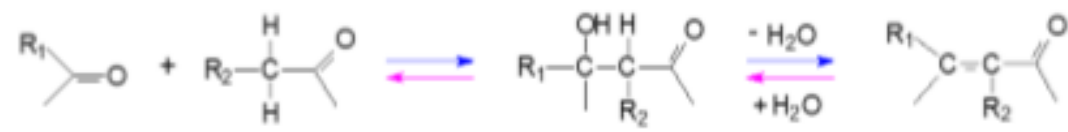

D

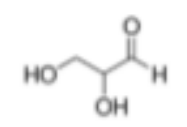

Glyceraldehyde

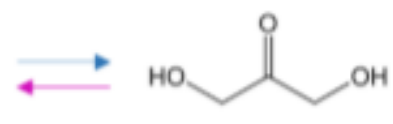

Dihydroxyacetone

E

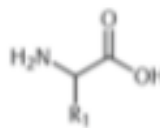<smiles>CCOC(=O)C=O</smiles><smiles>C1CCC1</smiles><smiles>[2H]C(C)O[C+]NC(=O)O</smiles> 
Figure 1

he most important reaction steps occuring during hydrothermal conversion of bio-based compounds. A: Hydroylsis of ethers, amines etc., B: Water elimination, C: Aldol addition and aldol condensation and their reverse reactions, D: Keto-Entol Tautomerisation (example), E: Strecker degradation

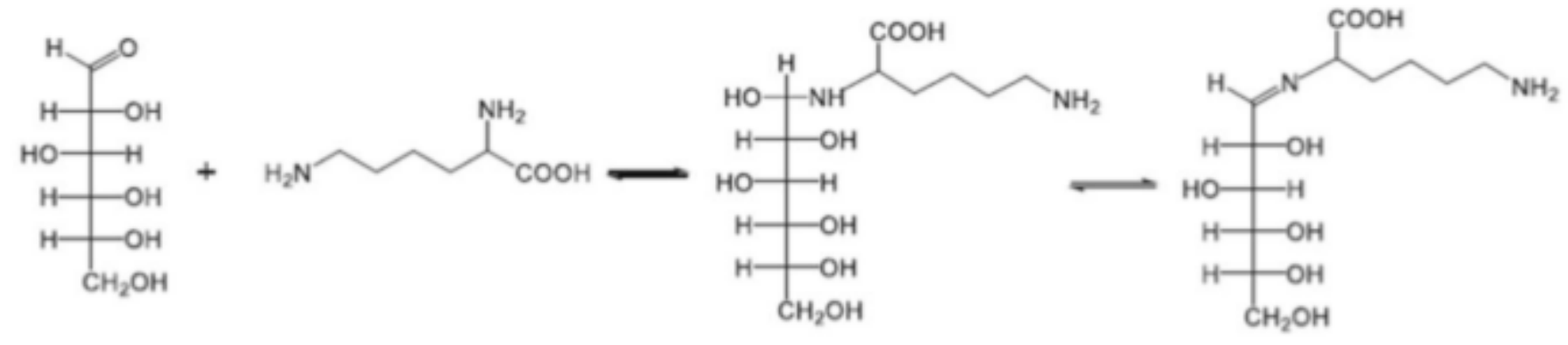

Glucose

Lysine

Glycosylamines

Shiff base

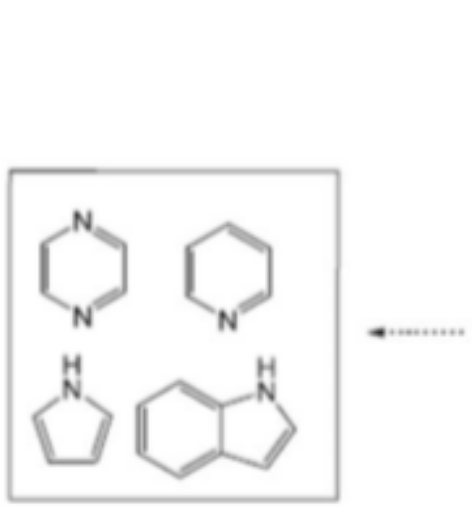

$\mathrm{N}$-containing compounds

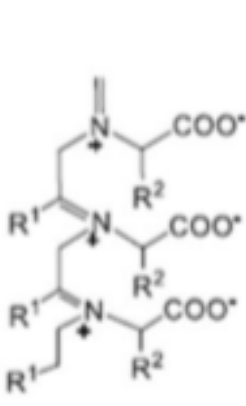

Melanoidins

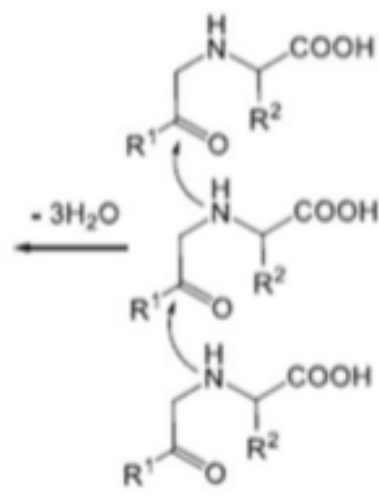

$\times 3$

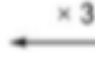

Amadori compound<smiles>CC(O)C(O)C(O)CO</smiles><smiles>[1H]CCCCN</smiles>

\section{Figure 2}

Proposed mechanisms of Maillard reaction pathways during HTC, reprinted with kind permission of [26] 


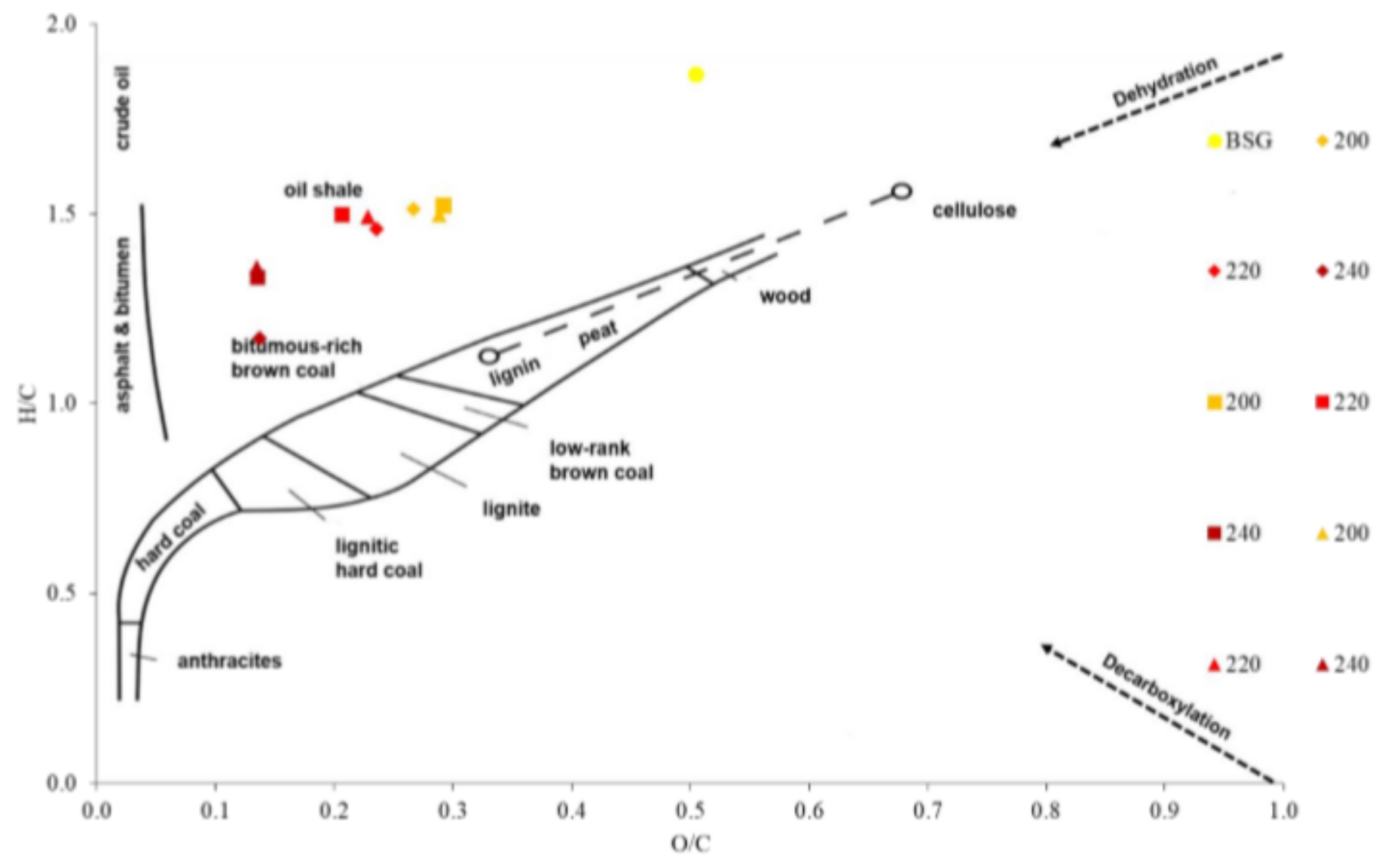

Figure 3

Coalification degree of hydrochars obtained from hydrothermal carbonization of brewer's spent grains with water and after recirculation of its process water in two further steps at $200,220,240{ }^{\circ} \mathrm{C}$ for 2 hours (e.g. 2nd 220) illustrated in the van Krevelen diagram by plotting $\mathrm{H} / \mathrm{C}$ atomic ratios versus $\mathrm{O} / \mathrm{C}$ atomic ratios. Whereas the rhombus-shaped data points stand for the initial HTC-run, the triangle-shaped and the square-shaped data points stand for the HTC-run after the 1st and the 2nd recirculation. BSG = Brewer's Spent Grains 


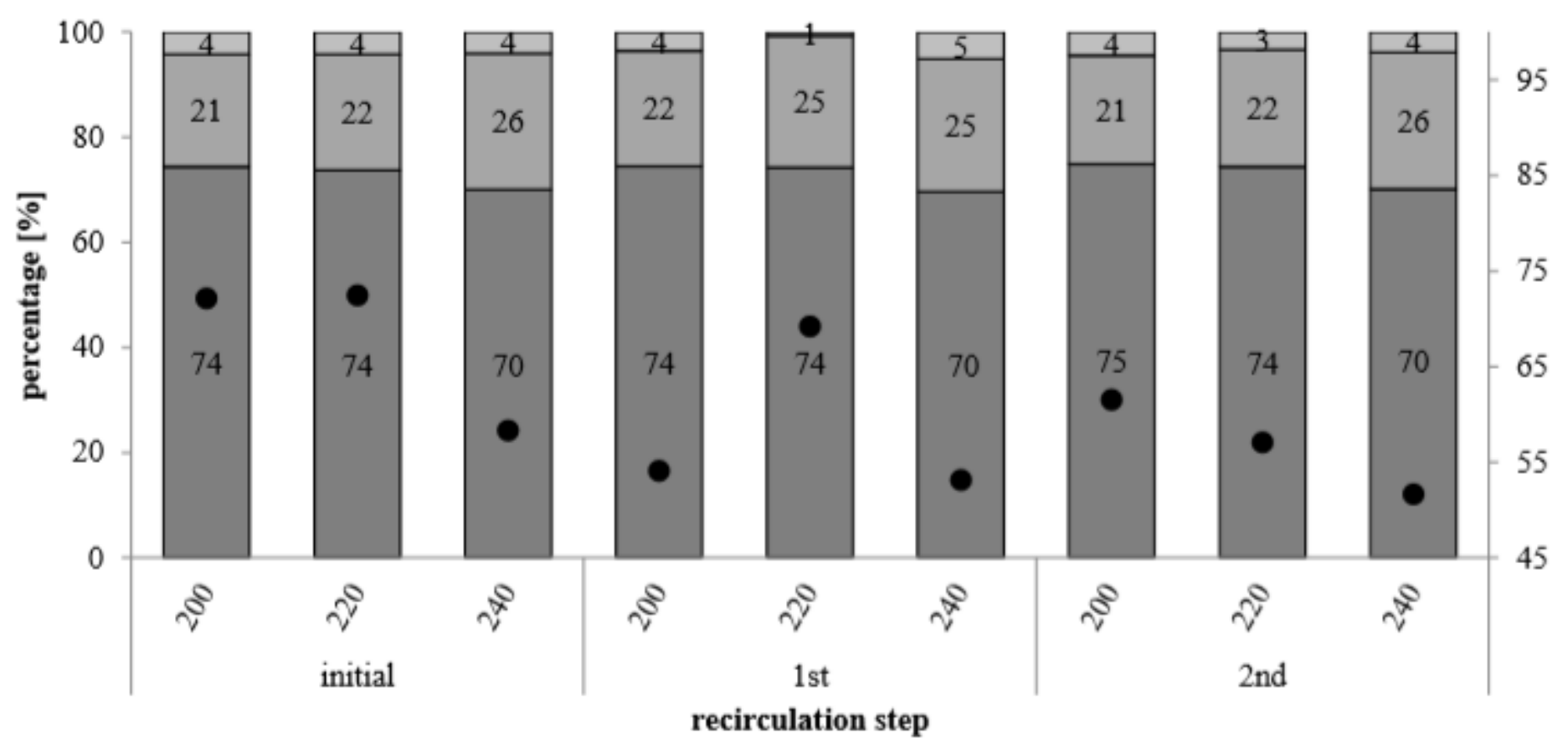

$\square \mathrm{C}$ in $\mathrm{HC} \quad \square \mathrm{C}$ in PW $\square \mathrm{C}$ in PG $\bullet \mathrm{Ceff}$

Figure 4

Carbon distribution (primary or left y-axis) and efficiencies (secondary or right y-axis) related to the product phases after Hydrothermal Carbonization of brewer's spent grains with water and two further recirculation steps of its process water. The process gas is assumed as $100 \% \mathrm{CO}$. $\mathrm{HC}=$ hydrochar; $\mathrm{PW}=$ process water; $P G$ = process gas; $\mathrm{CfIX}=$ fixed Carbon 


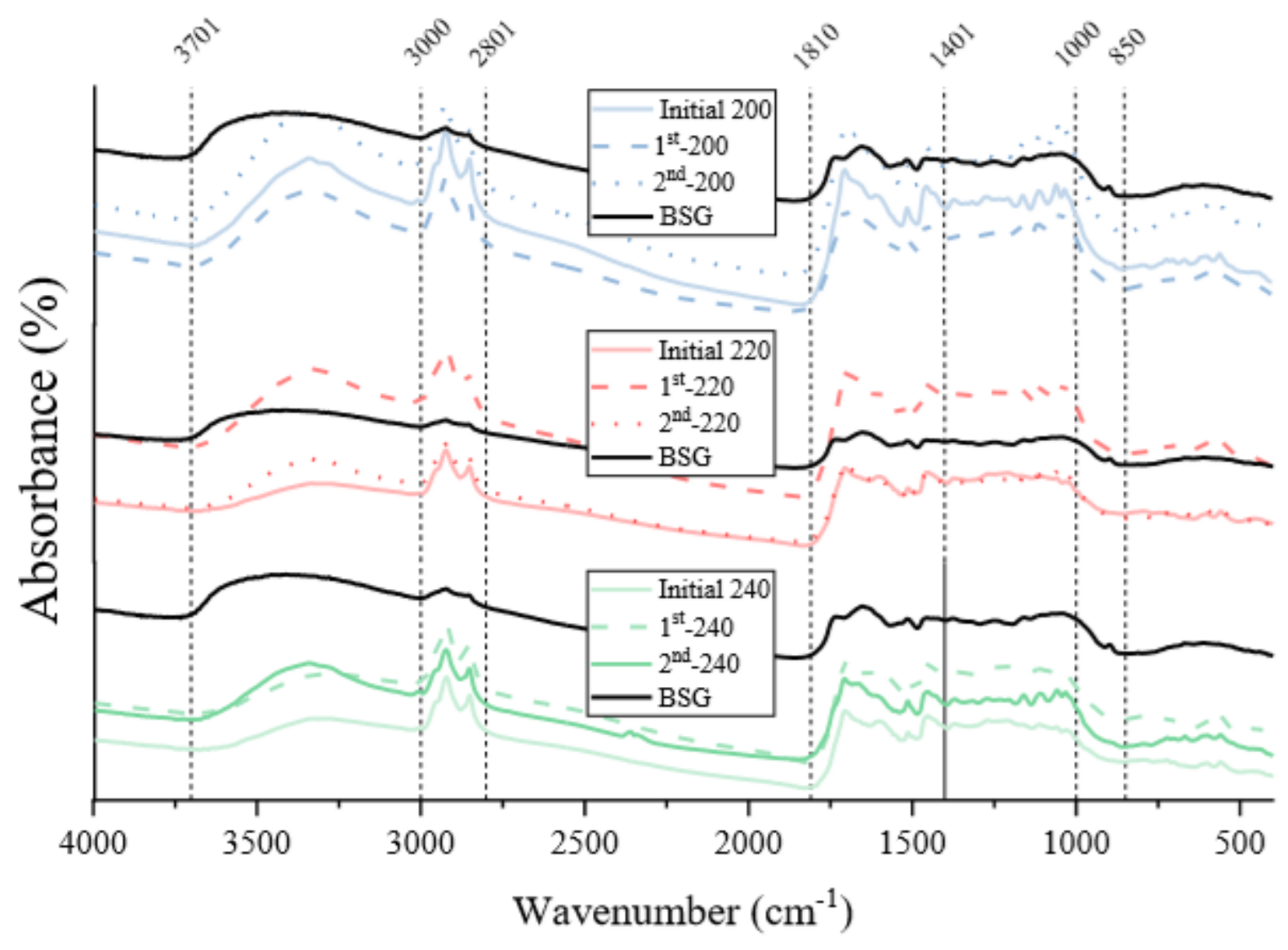

Figure 5

FT-IR of Brewer's Spent Grains (BSG) and its hydrochars produced at 200,220 and $240^{\circ} \mathrm{C}$ with water (initial) and after two recirculation steps of process water (1st, $2 \mathrm{nd}$ ) 


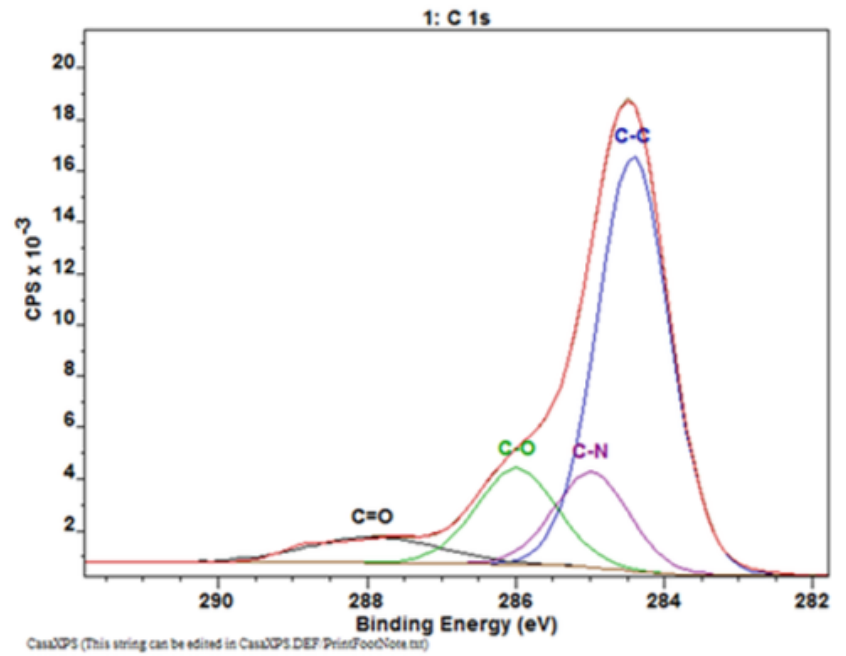

1: C 1s
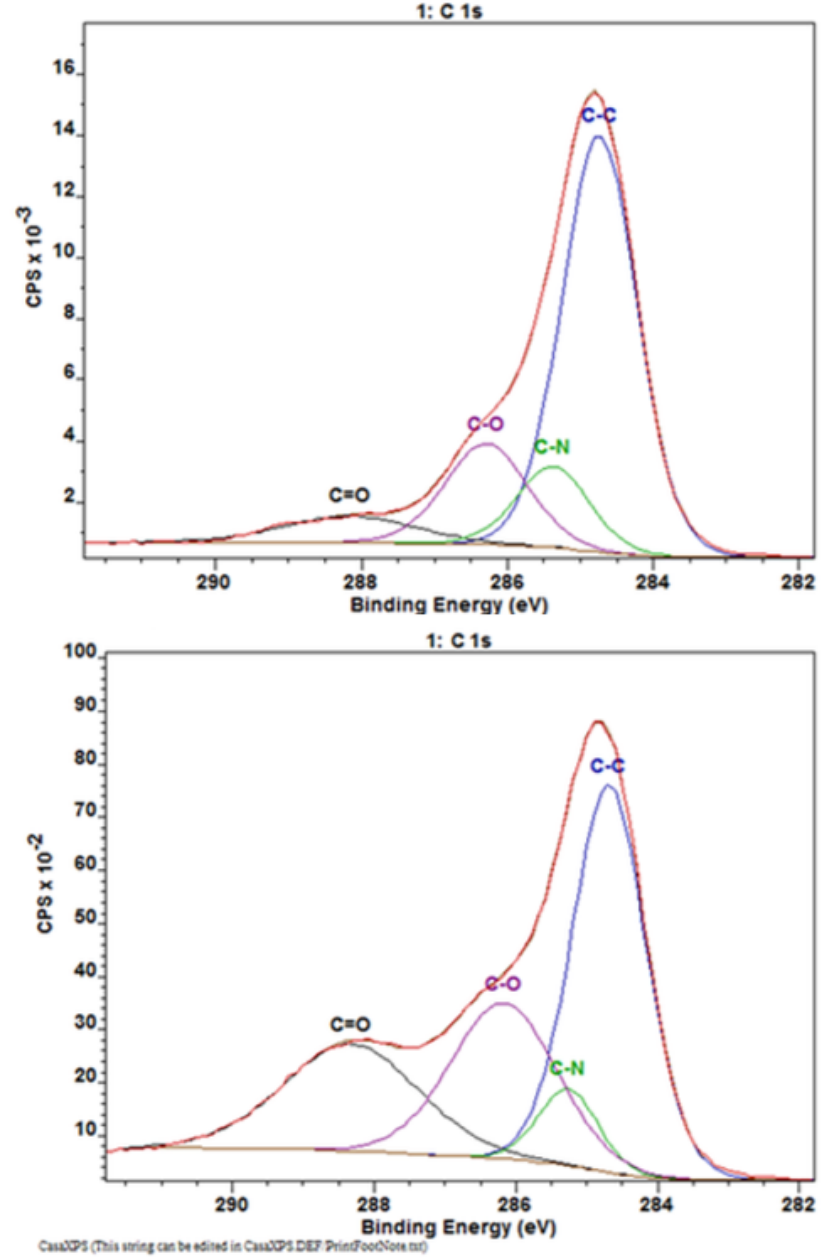

\section{Figure 6}

X-ray photoelectron spectroscopy of hydrochars produced from Brewer's spent grains at 220 with water (top - initial 220), after the 1st (middle - 1st 220) and 2nd recirculation of process water (bottom - 2nd 220). Only the range of the $\mathrm{C}-\mathrm{N}$ and $\mathrm{C}-\mathrm{O}$ bonds are shown 


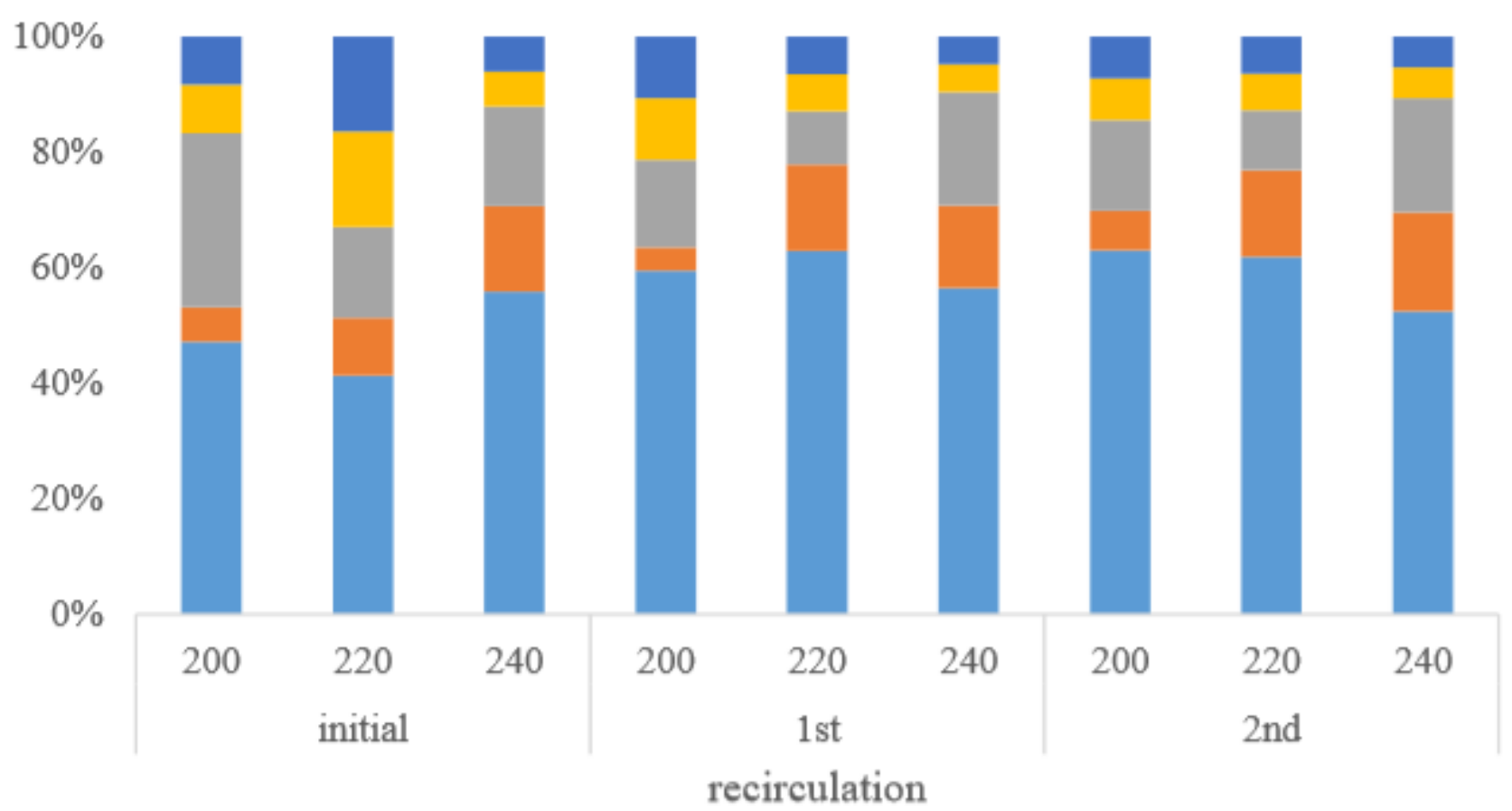

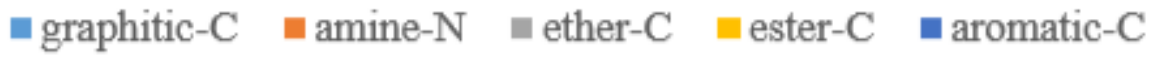

\section{Figure 7}

X-ray photoelectron spectroscopy of hydrochars produced from Brewer's spent grains at 200, 220 and $240{ }^{\circ} \mathrm{C}$ with water and after one or two recirculation steps of process water focussing on Carbon structures 


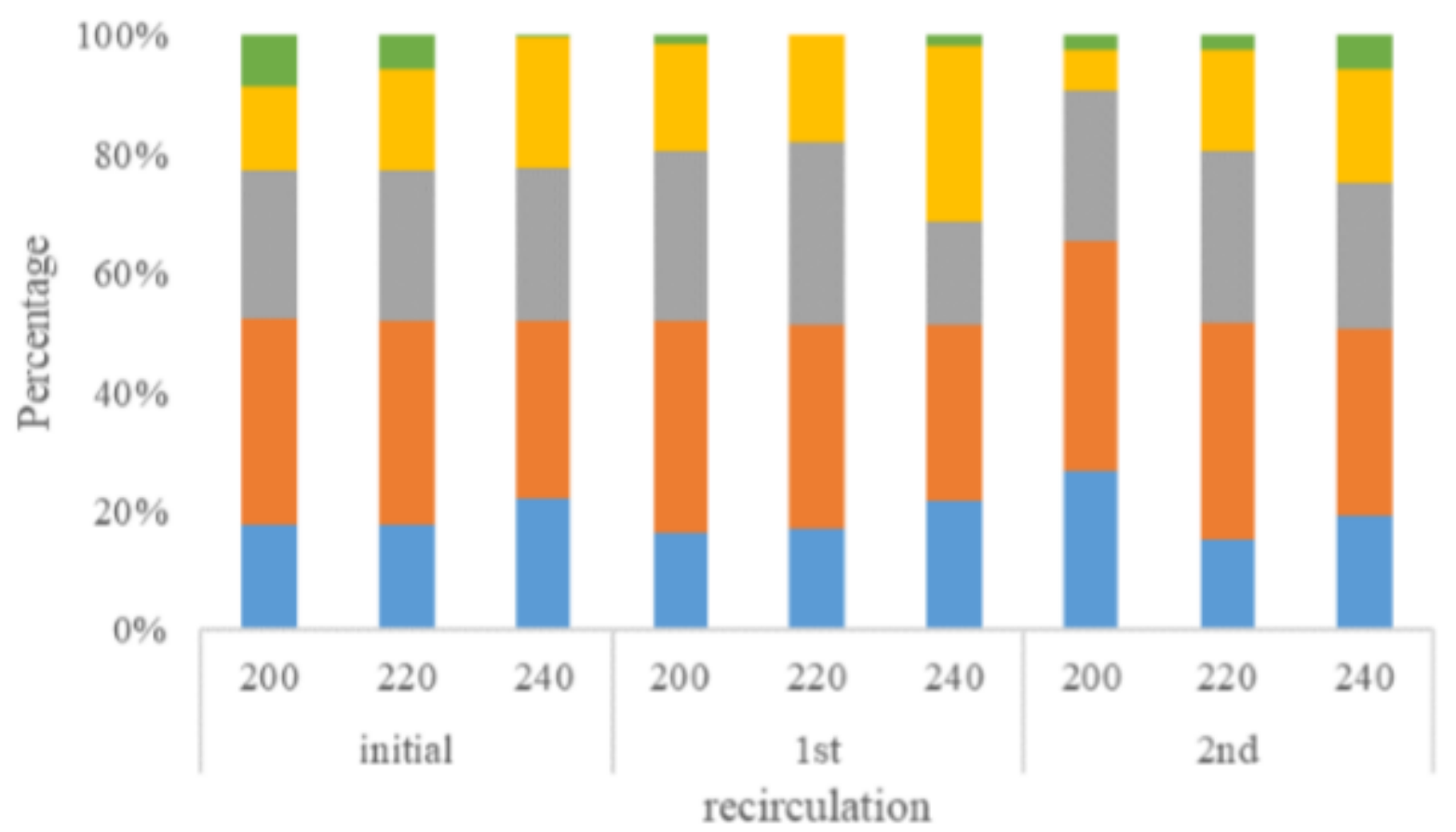

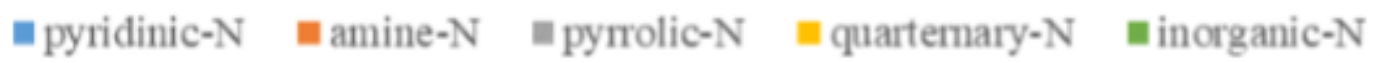<smiles>CNc1ccc[nH]1</smiles><smiles>[NH3+]</smiles>

\section{Figure 8}

X-ray photoelectron spectroscopy of hydrochars produced from Brewer's spent grains at 200, 220 and $240{ }^{\circ} \mathrm{C}$ with water and after two recirculation steps of process water regarding $\mathrm{N}$-containing structures. Examples for the different $\mathrm{N}$-species are also presented 


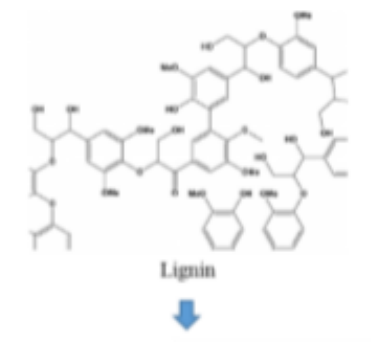

$\int_{\mathrm{OH}}^{-\mathrm{CH}_{3}}$

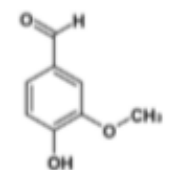

4-Hydroxy.3. methoxybensol

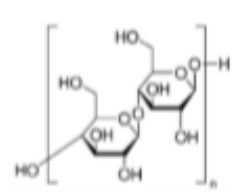

(Hemi.) Cellulose

$\sqrt{4}$

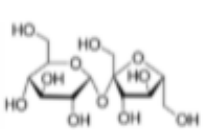

Sucrose

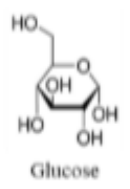

8
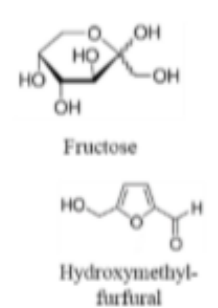

H, $\mathrm{H}_{\mathrm{OH}} \mathrm{H}_{\mathrm{OH}}$

Levulinic acid

Formic acid

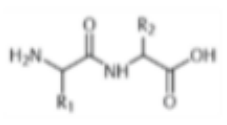

Protein
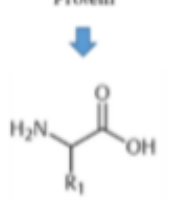

Amino acid

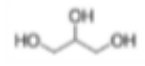

Glycerine

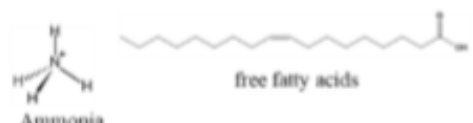

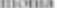<smiles>C1CC2CC1CN2</smiles>

Pyrrolidine

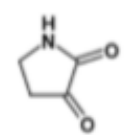

Pyrrolidinedione<smiles>c1cnccn1</smiles>

Propenoic acid
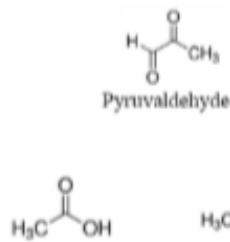

Acetic acid

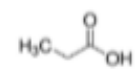

Propionic acid

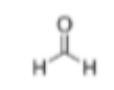

Formaldehyde

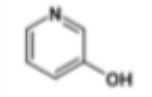

3-Hydroxy-Pyridin Pyrrolidine derivatives $1^{\text {t }}$ Generation:

Biomass

components

$2^{20}$ Generation

\section{8}

$3^{\text {st }}$ Gencration

8

$4^{\text {to }}$ Generation + Hydrochar

\section{Figure 9}

Scheme of reaction products detected in the process water after hydrothermal carbonization of lignocellulosic biomass classified into 4 gnerations depending on their accumulation 


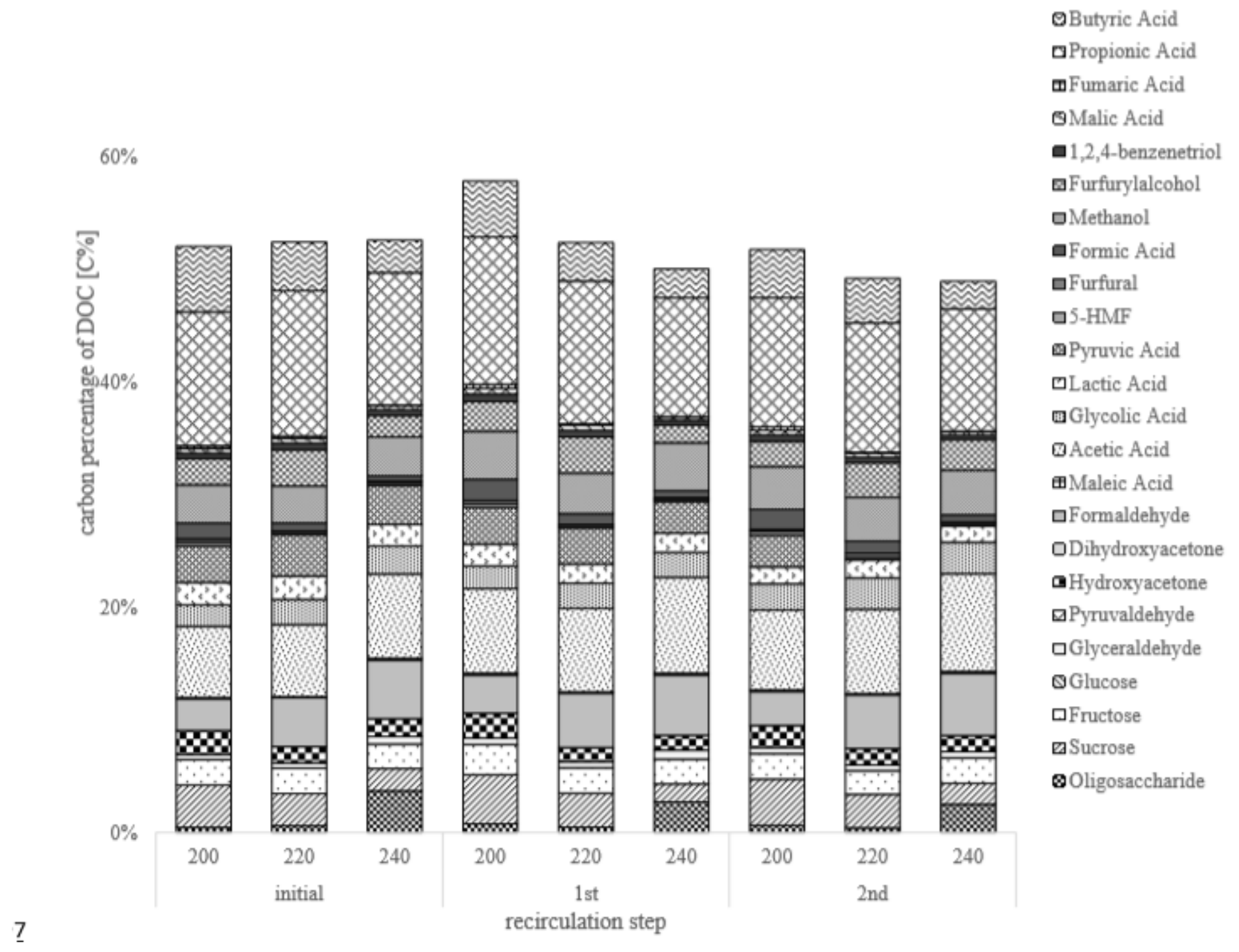

Figure 10

Carbon percentages of detected carbohydrate-based reaction products in the process waters from hydrothermal carbonization experiments with brewer's spent grains in distilled water (initial) as well as recirculated processs water (1st, 2 nd recirculatgion step) related to the dissolved organic carbon (DOC) 


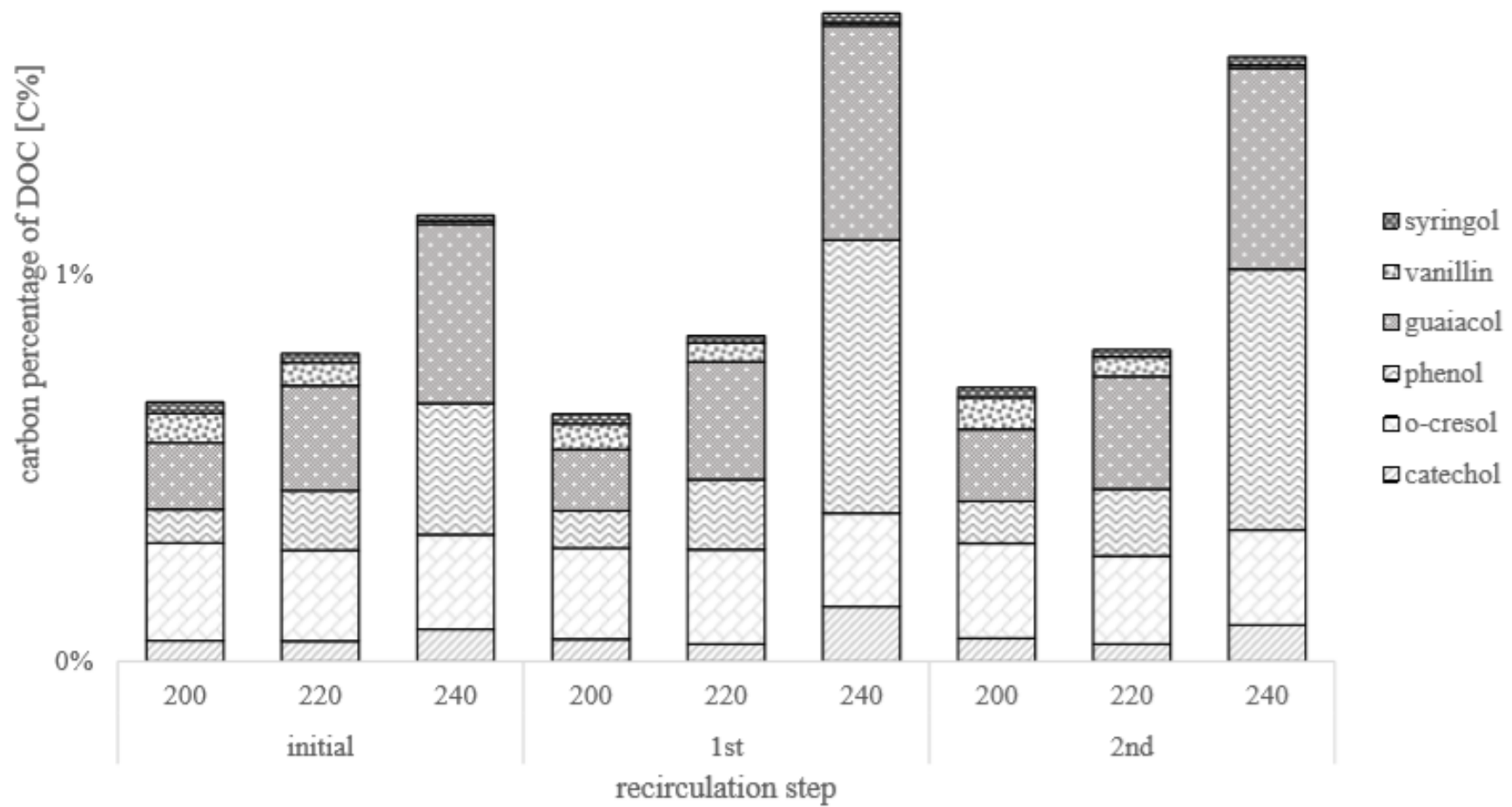

Figure 11

Carbon percentages of detected lignin related reaction products in the process waters from hydrothermal carbonization experiments with brewer's spent grains in water (initial) as well as recirculated processs water ( $1 \mathrm{st}+2 \mathrm{nd}$ recirculation step) related to the dissolved organic carbon (DOC). Syringol $=2,6-$ dimethoxyphenol, 4-Hydroxy-3-methoxybenzaldehyd = vanilin, 2-methoxy-phenol = guaiacol, 2-methylphenol $=$ o-cresol, 1,2-dihydroxybenzene $=$ catechol 


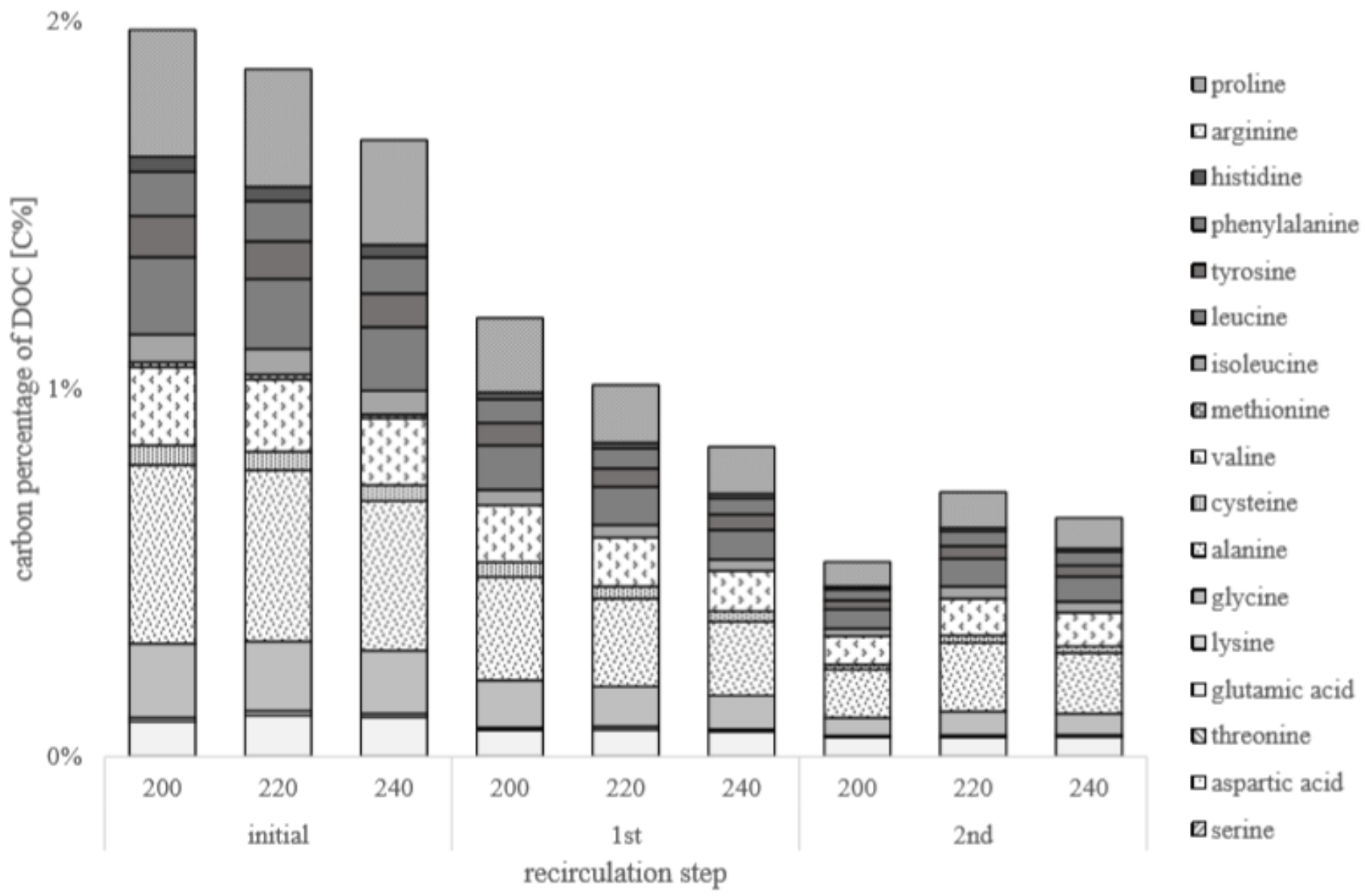

Figure 12

Carbon percentages of detected protein-related reaction products in the process waters from hydrothermal carbonization experiments with brewer's spent grains in water (initial) as well as recirculated processs water (1st and 2 nd recirculatgion) related to the dissolved organic carbon (DOC)

\section{Supplementary Files}

This is a list of supplementary files associated with this preprint. Click to download.

- graphicalabstract20210210.pdf

- supplementarymaterials20210210.pdf 